\title{
The influence of ecological infrastructures adjacent to crops on their carabid assemblages in intensive agroecosystems
}

\author{
Emilie Pecheur ${ }^{\text {Corresp., 1, } 2}$, Julien Piqueray ${ }^{3}$, Arnaud Monty ${ }^{1,2}$, Marc Dufrêne ${ }^{1,2}$, Grégory Mahy ${ }^{1,2}$ \\ ${ }^{1}$ Gembloux Agro-Bio Tech, Biodiversity and Landscape, University of Liège, Gembloux, Belgium \\ 2 Gembloux Agro-Bio Tech, TERRA-AgriculturelsLife, University of Liège, Gembloux, Belgium \\ 3 Natagriwal asbl, Gembloux, Belgium \\ Corresponding Author: Emilie Pecheur \\ Email address: epecheur@doct.uliege.be
}

Background. Conserving biodiversity and enhancing ecosystem services of interest in intensive agroecosystems is a major challenge. Perennial ecological infrastructures (Els), such as hedges and grassy strips, and annual El under Agri-Environment Schemes appear to be good candidates to promote both. Our study focused on carabids, an indicator group responding both at the species and functional trait level to disturbances and supporting pest control and weed seed consumption services.

Methods. We compared carabid assemblages at the species and functional traits levels, sampled via pitfall trapping, in three types of Els (hedges, grassy strips and annual flower strips) and crops. We also tested via GLMs the effect of (1) the type of El at the crops' border and (2) the distance from the crops' border (two meters or 30 meters) on carabid assemblages of crops. Tested variables comprised: activitydensity, species richness, functional dispersion metrics (FDis) and proportions of carabids by functional categories (Diet: generalist predators/specialist predators/seed-eaters; Size: small/medium/large/very large; Breeding period: spring/autumn).

Results and Discussion. Carabid assemblages on the Principal Coordinate Analysis split in two groups: crops and Els. Assemblages from all sampled Els were dominated by mobile generalist predator species from open-land, reproducing in spring. Assemblages of hedges were poor in activity-density and species richness, contrarily to grassy and annual flower strips. Differences in carabid assemblages in crops were mainly driven by the presence of hedges. The presence of hedges diminished the CWM size of carabids in crops, due to an increased proportion of small $(<5 \mathrm{~mm})$ individuals, while distance from crops' border favoured large (between 10-15mm) carabids. Moreover, even if they were attracted by Els, granivorous carabid species were rare in crops. Our results underlie the importance of local heterogeneity when adapting crops' borders to enhance carabid diversity and question the relevance of hedge implantation in intensive agrolandscapes, disconnected from any coherent ecological network. Moreover, this study emphasizes the difficulty to modify functional assemblages of crops for purposes of ecosystem services development, especially for weed seed consumption, as well as the role of distance from the crops' border in the shaping of crop carabid assemblages. 
1 The influence of ecological infrastructures adjacent to crops on their carabid

2 assemblages in intensive agroecosystems

3

4 Emilie Pecheur ${ }^{1,2}$, Julien Piqueray ${ }^{3}$, Arnaud Monty ${ }^{1,2}$, Marc Dufrêne ${ }^{1,2}$, Grégory Mahy $y^{1,2}$ 5

$6{ }^{1}$ Gembloux Agro-Bio Tech, Biodiversity and Landscape, University of Liège, Gembloux, 7 Belgium

$82^{2}$ Gembloux Agro-Bio Tech, TERRA-AgriculturelsLife, University of Liège, Gembloux, 9 Belgium

$10{ }^{3}$ Natagriwal asbl, Gembloux, Belgium

12 Corresponding Author:

13 Emilie Pecheur ${ }^{1}$

14 Passage des Déportés 2, 5030 Gembloux, Belgium

15 Email address: epecheur@uliege.be

17 Abstract

18 Background. Conserving biodiversity and enhancing ecosystem services of interest in intensive agroecosystems is a major challenge. Perennial ecological infrastructures

20 (Els), such as hedges and grassy strips, and annual El under Agri-Environment

21 Schemes appear to be good candidates to promote both. Our study focused on

22 carabids, an indicator group responding both at the species and functional trait level to

23 disturbances and supporting pest control and weed seed consumption services. 
24 Methods. We compared carabid assemblages at the species and functional traits 25 levels, sampled via pitfall trapping, in three types of Els (hedges, grassy strips and annual flower strips) and crops. We also tested via GLMs the effect of (1) the type of El at the crops' border and (2) the distance from the crops' border (two meters or 30 meters) on carabid assemblages of crops. Tested variables comprised: activity-density, species richness, functional dispersion metrics (FDis) and proportions of carabids by functional categories (Diet: generalist predators/specialist predators/seed-eaters; Size: small/medium/large/very large; Breeding period: spring/autumn).

Results and Discussion. Carabid assemblages on the Principal Coordinate Analysis split in two groups: crops and Els. Assemblages from all sampled Els were dominated by mobile generalist predator species from open-land, reproducing in spring. Assemblages of hedges were poor in activity-density and species richness, contrarily to grassy and annual flower strips. Differences in carabid assemblages in crops were mainly driven by the presence of hedges. The presence of hedges diminished the CWM size of carabids in crops, due to an increased proportion of small $(<5 \mathrm{~mm})$ individuals, while distance from crops' border favoured large (between 10-15mm) carabids. Moreover, even if they were attracted by Els, granivorous carabid species were rare in crops. Our results underlie the importance of local heterogeneity when adapting crops' borders to enhance carabid diversity and question the relevance of hedge implantation in intensive agrolandscapes, disconnected from any coherent ecological network. Moreover, this study emphasizes the difficulty to modify functional assemblages of crops for purposes of ecosystem services development, especially for weed seed 
46 consumption, as well as the role of distance from the crops' border in the shaping of

47 crop carabid assemblages.

48 Introduction

49 It is well acknowledged that intensive agriculture, the dominating production model in

50 Europe, put farmland biodiversity in jeopardy (Donald et al., 2001; Stoate et al., 2001).

51 This raises concerns since biodiversity has been linked to the efficient and durable

52 delivery of ecosystem services in agroecosystems. One of the most studied taxa in

53 agroecosystems, both for its contribution to ecosystem services and as an indicator

54- - group (Holland and Luff, 2000), are carabids. Carabids respond to habitat changes and

55 disturbances (Brooks et al., 2012), causing shifts in community assemblages at the

56 species and functional traits levels (Hanson et al., 2016; Kotze and O'Hara, 2003). From

57 an agronomic point of view, they are potential providers of two ecosystem services of

58 interest in agroecosystems: pest control (Kromp, 1999) and weed seeds removal

59 (Bohan et al., 2011).

60 Preserving carabid diversity in agrolandscapes goes along with the implementation of a

61 green network of ecological infrastructures (Els). Indeed, carabid communities appear

62 to benefit from spatial landscape heterogeneity (Neumann et al., 2016). Increased

63 habitat type diversity, as well as the presence of linear features varying in length and

64 composition, have positive effects on carabid community compositions (Duflot et al.,

65 2016, 2017; Fahrig et al., 2015; Woodcock et al., 2005). Conservation of source

66 habitats must be planned, such as forested patches and permanent grasslands (Purtauf

67 et al., 2005), and completed by a network of less disturbed perennial linear elements 
68

69

70

71

72

73

74

75

76

77

78

79

80

81

82

84

85

86

87

88

89

90

adjacent to fields, such as hedges and grassy strips (Fournier and Loreau, 2001).

Potentially acting as connection elements, allowing species to spread into the fields (Hof and Bright, 2010; Labruyere et al., 2016, 2017), perennial linear elements are also of great importance to preserve locally biodiversity in the fields, notably by providing refuge areas or overwintering sites (Fournier and Loreau, 2001; MacLeod et al., 2004).

In the European Union, perennial elements as well as a variety of annual flower strips can be established under the framework of Agri-Environment Schemes (AES). Different seed mixes, aiming at various environmental purposes, are sown each year in a ploughed strip along crop borders. Less disturbed than crops, since chemical inputs are prohibited, these strips could attract a variety of border-specific carabids species (Saska et al., 2007). When sown along a perennial El, annual flower strips could also enhance carabid diversity, thanks to the additive effect of both habitats (Boetzl et al., 2016).

The successful establishment of communities of arthropods in Els is largely constrained by local and landscape scales (Gabriel et al., 2010). The potential of AES regarding biodiversity support in impoverished agrolandscapes may thus be limited (Kleijn et al., 2006), a fact underlying the theory that AES will perform best in moderately complex agrolandscapes (Concepción et al., 2012). Still, intensive agrolandscapes, either having undergone radical landscape simplification or being historically intensive (i.e. run under an open-field regime), represent a large share of the potential areas where biodiversity could benefit from the implementation/conservation of Els. Several studies have explored carabid assemblages in agrolandscapes dominated by a bocage pattern undergoing a loss of connectivity and a consequent fragmentation (Baudry et al., 2000; Fournier and Loreau, 2001; Neumann et al., 2016). Regarding the influence of crops on 
91 carabids (Eyre et al., 2013), historically intensive agroecosystems are likely to have 92 different carabid beetles assemblages.

93 Addressing ecological functionality of carabid assemblages in intensive agroecosystems 94 requires to consider the diversity of functional traits within the communities. The interest 95 of integrating functional traits to the usual diversity indices is twofold. First, species

96 richness alone is neither the best explanation nor the insurance of ecosystem

97 functioning (Cadotte et al., 2011). Second, landscape characteristics shape

98 communities by a filtering operating on their functional traits (De Palma et al, 2015;

99 Duflot et al., 2014b). Eventually, this filtering applies a selection pressure on defined 100 functional groups and may lead to a homogenisation of communities (Barbaro and Van 101 Halder, 2009). Therefore, functional traits facilitate the inclusion of landscape history as 102 a factor shaping existing species assemblages, easing the generalisation of results 103 (Gagic et al., 2015).

104 Local planning, however, must not be neglected in the mitigation of biodiversity erosion 105 in agroecosystems and the maintenance of ecosystem services. Therefore, this study 106 focusing on historically intensive agrolandscapes aims at (1) comparing carabid 107 assemblages and functional groups in three types of Els: grassy strips (perennial), 108 hedges (perennial) and annual flower strips to evaluate the potential of these Els in 109 biodiversity conservation; (2) testing how the type of El can modify crop assemblages of 110 carabids at the field border and at 30 meters, for purposes of promoting pest and weed 111 seed control. 


\section{Materials \& Methods}

114 Three study sites were selected in southern Belgium (Fig.1a,b). Sampled fields were all

115 flat, shared the same biogeographical context and were situated at the same altitude. In

116 ArcMap 10.2, we calculated for each crop the cover percentage of several land use

117 categories (see Annex 1) within radii of 50 and 500 meters, distances known to

118 influence carabid assemblages (Aviron et al., 2005). Data for land cover was provided

119 by the shapefile TOP10V (@ IGN, 2018). Located on loamy soils, sites were all

120 intensively managed, surrounded by at least $75 \%$ of cropped area at 50 and $500 \mathrm{~m}$

121 (Annex 1). Percentage of agricultural area of ecological potential, i.e. set of (semi-)

122 natural elements present on arable lands, was comprised between 1.5 and $5 \%$

123 (Piqueray et al., 2013). Eventually, an ANOSIM confirms that carabid communities from

124 the crops were similar between the three study sites ( $p$-value $=0.086, R=0.063$ )

125 (Clarke \& Warwick, 2001). This is corroborated with results from homogeneity of groups

126 dispersion, tested with 'betadisper' from the 'vegan' package (Oksanen et al., 2015)

127 (ANOVA : $F(2,21)=0.942, p$-value $=0.40)$. The above-mentioned description attests that

128 the three study sites had similar land use occupancy, as well as were intensively

129 managed. We therefore consider that landscape context shaping carabid assemblages

130 was similar between our sites and will not take it any further into account for the next

131 analyses.

132 In each study site, four configurations of Els bordering cereal crops were chosen

133 (Fig.1c). Two configurations displayed a single perennial El, hedge or grassy strip, while

134 the two others showed an association of each type of perennial El to an annual flower 
135 strip. Annual flower strips were managed under regional AES. Installed for a minimum

136 of five years, these strips adjacent to cropped fields are ploughed every year and sown

137 with a mix of cabbage and winter or spring cereals, to which are usually added radish,

138 flax, buckwheat and sunflowers. The purpose of annual flower strips is to provide food

139 resources to farmland birds during autumn and winter, as well as a refuge for small

140 farmland fauna. Grassy strips coupled to annual flower strips were also under AES

141 management. Sown along the annual flower strip, they were installed for a minimum of

142 five years, normally left uncut and made of a mix of grass species (i.e. mix of reference:

143 45\% Dactylis glomerata, 25\% Phleum pratense and 30\% Festuca rubra or 75\% Dactylis

144 glomerata and 25\% Festuca rubra).

145 Cereal crops (predominantly wheat, but barley, oat and spelt were present as well),

146 along with three categories of Els (hedges, grassy strips, annual flower strips), were

147 thus sampled. Both in crops and Els, a transect line was drawn lengthwise the

148 bordering El (see Fig 1.c), on which were placed pitfall traps to collect carabids. In

149 crops, two transects were defined: the first at two meters from the border and the

150 second at 30 meters. Traps were polypropylene cups of $8.5 \mathrm{~cm}$ diameter, half-filled with

151 a mix of polyethylene glycol, diluted to $30 \%$, and a few drops of neutral liquid soap.

152 Their openings were flush with the soil surface, and a metal grid (heightened of $1.5 \mathrm{~cm}$,

153 with a mesh size of $1 \mathrm{~cm}$ ) was used above every trap to prevent catching rodents and

154 other small vertebrates. Three traps were equally spaced along every transect. Traps

155 were simultaneously open for seven days during the second week of May, June, July

156 and at the end of September 2016. Weather conditions were similar between sites

157 during catching sessions and in case of rain, no flooding occurred. 
158 Carabids were identified to species level using the identification keys of Coulon et al.

159 (2011 a, b) and Roger et al. (2013). A list of all species and their associated traits is 160 available in Table S2.

161 Statistical analysis and plots were computed with R (version 3.5.1, R Core Team, 2013).

162 Exploring composition of carabid communities in the different sampled configurations of 163 Els was performed using Principal Coordinate Analysis (PCoA). We plotted activity164 density per transect. Data was standardised to take into account missing traps by 165 averaging all individuals by traps over the whole trapping period. Then, the number of 166 individuals from the three traps was summed to obtain an activity-density value by 167 transect. A distance matrix of Bray-Curtis was computed from the activity-density data 168 set and root-transformed before the PCoA calculation in order to conserve its Euclidean 169 property.

170 Functional traits were used to analyse the structure of carabid assemblages. Selected 171 traits (Table 1) were either known to be response traits of carabids to landscape change 172 (i.e.,size and wing type, see Pakeman and Stockan, 2017) or inform about the potential 173 provisioning of ecosystem service (i.e., diet) or species biology (i.e., breeding period).

174 They were taken from the Ribera et al. (1999) and Dufrêne (1992) databases.

175 Functional trait diversity was estimated using functional dispersion metrics (FDis index) 176 from Laliberté and Legendre (2010). Cailliez correction for non-Euclidean distance was

177 applied to take into account the categorical traits. Table 1 displays the trait occurrences 178 for each El type and crop, completed by the community weighted mean (CWM) size.

179 To test the influence of the type of El and the distance to the crop edge on crop carabid 180 assemblages, we used General Linear Models (GLM) with the 'glm' call. 
181 This test was performed on a set of variables: carabid activity-density, species richness,

182 functional diversity index (FDis), proportions of carabid functional traits and community

183 weighted mean (CWM) size (see Table 1 for the traits categories). For the diet, we

184 grouped omnivorous and granivorous species as both can exert as weed seed

185 suppressor. We did not take into account the wing morphology since brachypterous

186 species were rare. Distribution models for the GLMs were visually selected via the

187 plotting of quantiles. Most variables followed a Gaussiandistribution, except activity-

188 density, granivorous carabids, large $(>10 \mathrm{~mm})$ and very large carabids $(>15 \mathrm{~mm})(\log$

189 distribution), and species richness (Poisson distribution). GLMs were run for each

190 variable, testing five models: $1^{\circ}$ El type * Distance; $2^{\circ}$ El type + Distance; $3^{\circ}$ Distance;

$1914^{\circ} \mathrm{El}$ type and $5^{\circ}$ the null model $(\sim 1)$.For each variable, we selected the best fitted

192 model using the Akaike Information Criterion (AIC; Burnham and Anderson 1998) with a

193 correction for small sample (AICc; Hurvich and Tsai,1989). Difference of AIC value from

194 the best model $(\triangle \mathrm{AICc})$ and AICc weight (wAICc) were used to rank the models.

195 Eventually, $p$-values were computed for models with a $\Delta \mathrm{AlC}_{\mathrm{c}}<2$. We used a deviance

196 table (Type III Wald chisquare tests) through the command 'Anova' from the package

197 'car' (Fox and Weisberg, 2011). If significance was detected, a Tukey contrast as post-

198 hoc test was applied to the model with the 'glht' command from 'multcomp' package

199 (Hothorn et al., 2008). Residuals from significant models were checked with spline-

200 correlograms from the package 'ncf' (Bjornstad, 2019) to detect patterns of spatial

201 autocorrelation. We eventually checked for the need of a correlation structure by using

202 GLS models, comparing the AIC of models with and without a correlation structure. 
203 As our data did not allow to test the site effect, we provided a descriptive table of the 204 values tested per variables (Table S3). This makes it possible to visualize whether the 205 reported effects were consistent between the three study sites.

\section{Results}

A total of 7405 carabids, belonging to 41 species (see Annex 2) were captured during

211 the trapping season. Of all species, 12 were represented by fewer than 10 individuals.

212 The first two axes of the PCoA (Fig.2a) explained $22.70 \%$ of the variability observed in 213 the dataset. A differentiation was observed along the first axis between crops and 214 bordering Els. Ecological infrastructures diverged along the second axis. Herbaceous 215 structures (grassy and annual flower strips) and crop at $2 \mathrm{~m}$ ) shared similarities, while 216 communities at $30 \mathrm{~m}$ in the crops and in hedges were more distinct. Activity-density of 217 carabid species characterising the crops was higher than those caught in the Els (Fig. $2182 b)$.

219 Activity-density was clearly higher in ploughed structures, i.e. crops and annual flower 220 strips, especially compared to hedges (Table 2). Species richness was fairly low in the 221 perennial Els compared to the annual El and the crops. Overall, the FDis index was 222 quite similar between the different Els and crops, ranging from 0.25 to 0.32 . The low 223 value observed in hedges $(0.25 \pm 0.12)$ was driven by the value from the site of Thuin. 
224 Table 1 presents the percentage of occurrence of selected traits categories and CWM 225 size for each El and for crops.

226 Small carabids $(<5 \mathrm{~mm})$ represented between 16 and $23 \%$ of the carabid assemblages 227 in Els and crops, peaking to $28 \%$ in annual flower strips. Hedges and grassy strips had 228 similar proportions of medium and large carabids (respectively around $45 \%$ and $27 \%$ ), 229 while in hedges more than $10 \%$ of caught carabids exceeded $15 \mathrm{~mm}$. CWM size was 230 identical in all Els and at $2 \mathrm{~m}$ from the crop border (around $8 \mathrm{~mm}$ ) but increased to 10 $231 \mathrm{~mm}$ in the crop at $30 \mathrm{~m}$ from theborder. This is attributable to the percentage of large 232 carabids $(10-15 \mathrm{~mm})$, accounting for more than $50 \%$ of all individuals caught further in 233 the crops. Very large carabids $(>15 \mathrm{~mm})$ tended to be scarce in all sampled elements. 234 Winged-phenotypes dominated in all of the Els and in crops. Brachypterous species 235 were rare (only two species were identified: Pterostichus madidus and Stomis pumicatus). Regarding diet, all of the Els and crops contained more than $73 \%$ of generalist predators. If specialist species were present in similar proportions, the percentage of omnivorous was higher in hedges and annual flower strips. Granivorous carabids were more abundant in annual flower strips and grassy strips. Spring-breeding carabid species were the most abundant in Els and crops, except at 30m from the crop 241 edge.

242 Results of the GLMs are fully presented in Table 3. Tested variables (Els and distance) 243 did not explain the patterns of species richness, FDis index and proportion of specialist 244 predators. For several variables, both the null model and another model had a $\Delta \mathrm{AICc}$ $245<2$ : in that case, the model explained by the tested factor was never significant (Table 246 4). The type of El modified the size and proportion of spring breeders in the crop 
247 assemblages (Table 4). The presence of a single hedge led to carabid assemblages of

248 smaller size (Fig.3a and 3b), with an increased proportion of spring breeders compared

249 to an association of grassy strip/annual flower strip (Fig. 3c). Distance tended to be

250 retained as an explanatory variable for other class sizes and diets but models were not

251 significant. Spline-correlograms (Fig. S1) did not display spatial auto-correlation in

252 residuals at short distances $(<5 \mathrm{~km})$, confirming the spatial independence of transects.

253 However, signals of potential negative auto-correlation in model residuals were present

254 at $30 \mathrm{~km}$ and $70 \mathrm{~km}$. Still, the addition of a correlation structure to the GLS models

255 showed no improvement: for all three variables, GLS models with the lower AIC values

256 are those without the correlation structure (Table 5). We thus conclude that models

257 without correlation structure are valid.

258

259

260

261

262 Discussion

263

264 The different sampled Els sheltered distinct assemblages of carabids, compared to 265 cropped fields. Regarding composition in functional traits, communities from Els and 266 crops were dominated by predator carabids from open land displaying a good ability to 267 disperse, and mostly reproducing in spring. The two last traits are known to mirror the 268 filtering initiated by landscape configuration on carabid assemblages (Duflot et al., 
269 2014b), selecting highly mobile species able to cope with crop disturbances. Even in the 270 absence of a control situation without any El, we suspect that the landscape context

271 largely shaped the pool of species and traits present in the agroecosystems and that 272 local management could only slightly modulate these (Woodcock et al., 2010; Trichard 273 et al., 2013).

274 Overall, sampled carabid assemblages showed a functional homogeneity, tempered by 275 the availability of Els. The similarity of FDis in crops bordered by different Els suggested 276 that even though these Els contributed to local diversity of carabid species, their 277 contribution to traits diversity may have been insufficient regarding the filtering exerted 278 by the intensive agrolandscapes. When unusual traits for carabid assemblages in crops 279 were detected, i.e. granivory, carabids were too few to raise functional diversity index 280 (FDis), as FDis weights species by their abundance.

281 Still, among the tested functional traits in crops, the size of carabids was affected by the 282 presence of single hedges. Community weighted mean (CWM) size of carabids in the 283 crops decreased, in response to the decline of large $(>10 \mathrm{~mm})$ carabids and the 284 increase of small carabids $(<5 \mathrm{~mm})$. The distance to the crop border conversely tended 285 to favour the proportion of large carabids. As the size of predator species plays a key 286 role in prey-predator relationships, in terms of consumed species and predation rate 287 (Rusch et al., 2015) pest control may be affected. The dominance of large carabid 288 species is suspected to favour intra-guild predation towards other carabid species of 289 smaller size or other potential predators may occur, possibly interfering with the desired 290 pest control (Prasad and Snyder, 2006). To the contrary, according to allometric laws 
291 (Brose, 2010), the larger proportion of small carabid species in the presence of hedges

292 could benefit to the consumption of small pests such as aphids.

293

294 The presence of single hedges also increased the proportion of spring breeders in the 295 crops. This suggests that single hedges are a refuge habitat of lower quality, at least for 296 some autumn breeding species. Poor habitat quality of hedges under anthropogenic 297 management is common (Magura et al., 2017) and could partly explain the questioning 298 results of hedges, characterized by a low diversity and activity-density of carabids. This contrasts with other studies where hedges, as a part of a coherent network such as bocage landscapes, were commonly identified as distinct habitats, hosting a mix of 301 forest and open-land species (Fournier and Loreau, 2001; Duflot et al., 2014a). This 302 was, however, not the case on our study sites, as hedges there were planted in open303 field landscapes.

Granivorous carabid species responded positively to the presence of grassy and annual flower strips adjacent to crops. As granivorous species are highly mobile in 306 agrolandscapes to exploit food resources (Labruyere et al., 2016), they benefit from the establishment of weeds in Els (Fried et al., 2009), from which they may feed on seeds 308 (Saska and Jarosik, 2001). Still, they hardly dispersed within the crops and showed no response to the type of El, as it has been observed by Boetzl et al. (2018). Literature 310 shows that bordering habitats have a limit of influence on crop species assemblages 311 (Roume et al., 2011). Acknowledging that some species show clear preferences for 312 either boundaries or field-edges (Saska et al., 2007), which may retain them from 313 dispersing within the neighbouring field (Boetzl et al., 2018), the role of Els in the 
314 enhancement of granivorous carabids in crops appeared limited in intensive

315 agroecosystems. Moreover, if distance from the edge tends to exert a selection

316 pressure on size, this could limit the range of granivorous carabid size diversity. As a

317 consequence, the variety of consumed seed may be restrained as carabid size

318 constrains seed preferences (Honek et al., 2007).

319 Though our results display clear trends, the lack of repetition of Els per site in our study 320 enables us to generalize them to intensive agrolandscapes. Still, our study addresses

321 two main issues: 1) the planting of single hedges for carabids in intensive agricultural 322 landscapes, outside any forested network and 2) the role of granivorous carabid species 323 in the control of weed seed in crops. As single hedges turned out to be of weak support 324 to carabids from agroecosystems, potentially impeding their movement in the landscape 325 (Mauremooto et al., 1995), we encourage a deeper investigation of their role in intensive 326 agrolandscapes. Regarding granivorous carabid species, even if the activity-density of 327 carabids does not ensure the delivery of an ecosystem service (Saska et al., 2008), we 328 suggest as an experimental perspective to investigate the presence of granivorous 329 carabids in crops during ploughing period. As ploughing exposes weed seeds from the seed bank, it is likely an adequate time of action for their consumption by carabids if

331 they can exert any control. Concomitantly, as distance from the border appears as a 332 potential limiting factor to the dispersion of carabids within crops, we enjoin to 333 investigate the spatial arrangement of El in agroecosystems as a research perspective 334 to promote efficient and stable pest and weed control in crops.

\section{Conclusion}


336 Our results support that carabids can be very diverse in intensive agroecosystems

337 (Vanbergen et al., 2005), though displaying a homogenisation of functional traits.

338 Carabids fanned out in the different habitats at their disposal quite quickly, as exampled

339 by the colonization of annual flower strips by granivorous species. Thus, adapting field

340 edges with variate strips provide habitats and food resources to carabid species

341 infrequent in crops or offer an adequate refuge to crop species. Differences in carabid

342 assemblages in crops were mainly driven by the presence of hedges. Changes

343 concerned the CWM size, which decreased in the presence of a hedge while the

344 proportion of large carabids increased with distance from the crop border. Considering

345 carabid assemblages and functional guilds, our results highlight that the role of

346 ecological infrastructures in the enhancement of ecosystem services may be limited by

347 the supported pool of species and in view of these species habitat preferences, notably

348 for weed seed removal. To conclude, if the diversification of Els is to be pursued in

349 intensive agrolandscapes, their installation would benefit from a landscape-inspired

350 planification, based on a networking of farmers' engagements to allow the development

351 of an efficient matrix of agri-environment schemes.

352

353

354

355

356

357 Acknowledgements 
358 The authors thank Benjamin Daigneux who identified the sampled carabids.

359

360

\section{References}

361 Aviron, S., Burel, F., Baudry, J., Schermann, N., 2005. Carabid assemblages in

362 agricultural landscapes: Impacts of habitat features, landscape context at different

363 spatial scales and farming intensity. Agric. Ecosyst. Environ. 108, 205-217.

364 https://doi.org/10.1016/j.agee.2005.02.004

365 Barbaro, L., Van Halder, I., 2009. Linking bird, carabid beetle and butterfly life-history 366 traits to habitat fragmentation in mosaic landscapes. Ecography (Cop.). 32, 321333. https://doi.org/10.1111/j.1600-0587.2008.05546.x

Baudry, J., Bunce, R.G.H., Burel, F., 2000. Hedgerows: An international perspective on 369 their origin, function and management. J. Environ. Manage. 60, 7-22.

370 https://doi.org/10.1006/jema.2000.0358

371

372

373

374

375

376

377

Bjornstad O.N., 2019. ncf: Spatial Covariance Functions. R package version 1.2-8. https://CRAN.R-project.org/package=ncf

Boetzl, F.A., Schneider, G., Krauss, J., 2016. Asymmetric carabid beetle spillover between calcareous grasslands and coniferous forests. J. Insect Conserv. 20, 4957. https://doi.org/10.1007/s10841-015-9838-6

Boetzl, F.A., Krimmer, E., Krauss, J., Steffan-Dewenter, I., 2018. Agri-environmental schemes promote ground-dwelling predators in adjacent oilseed rape fields: 
Diversity, species traits and distance-decay functions. J. Appl. Ecol. 1-11.

379 https://doi.org/10.1111/1365-2664.13162

380

381

382

383

384

385

386

387

388

389

390

391

392

393

394

395

396

Bohan, D.A., Boursault, A., Brooks, D.R., Petit, S., 2011. National-scale regulation of the weed seedbank by carabid predators. J. Appl. Ecol. 48, 888-898. https://doi.org/10.1111/j.1365-2664.2011.02008.x

Brooks, D.R., Bater, J.E., Clark, S.J., Monteith, D.T., Andrews, C., Corbett, S.J., Beaumont, D.A., Chapman, J.W., 2012. Large carabid beetle declines in a United Kingdom monitoring network increases evidence for a widespread loss in insect biodiversity. J. Appl. Ecol. 49, 1009-1019. https://doi.org/10.1111/j.13652664.2012.02194.x

Brose, U., 2010. Body-mass constraints on foraging behaviour determine population and food-web dynamics. Funct. Ecol., 24, 28-34. https://doi.org/10.1111/j.1365$\underline{2435.2009 .01618 . x}$

Burnham KP, Anderson DR., 1998. Model Selection and Inference: a Practical Information-Theoretic Approach. Springer-Verlag, New York. https://doi.org/10.1007/978-1-4757-2917-7 3

Cadotte, M.W., Carscadden, K., Mirotchnick, N., 2011. Beyond species: Functional diversity and the maintenance of ecological processes and services. J. Appl. Ecol. 48, 1079-1087. https://doi.org/10.1111/j.1365-2664.2011.02048.x 
397 Clarke, K.R. and Warwick, R.M., 2001. Change in Marine Communities: An Approach to 398 Statistical Analysis and Interpretation. 2nd Edition, PRIMER-E, Ltd., Plymouth 399 400 401 Marine Laboratory, Plymouth. Concepción, E.D., Díaz, M., Kleijn, D., Báldi, A., Batáry, P., Clough, Y., Gabriel, D., Herzog, F., Holzschuh, A., Knop, E., Marshall, E.J.P., Tscharntke, T., Verhulst, J., 2012. Interactive effects of landscape context constrain the effectiveness of local agri-environmental management. J. Appl. Ecol. 49, 695-705. https://doi.org/10.1111/j.1365-2664.2012.02131.x

404

405

406

407

408

409

410

411

412

413

414

415

416

417

Coulon, J., Pupier, R. and Queinnec, E., 2011a. Faune n 94 - Coléoptères Carabidae de France. Faune de France.353p

Coulon, J., Pupier, R. and Queinnec, E., 2011b. Faune n 94 - Coléoptères Carabidae de France. Faune de France.313p

De Palma, A., Kuhlmann, M., Roberts, S.P.M., Potts, S.G., Börger, L., Hudson, L.N., Lysenko, I., Newbold, T., Purvis, A., 2015. Ecological traits affect the sensitivity of bees to land-use pressures in European agricultural landscapes. J. Appl. Ecol. 52, 1567-1577. https://doi.org/10.1111/1365-2664.12524

Donald, P.F., Green, R.E., Heath, M.F., 2001. Agricultural intensification and the collapse of Europe's farmland bird populations. Proc. Biol. Sci. 268, 25-29. https://doi.org/10.1098/rspb.2000.1325

Duflot, R., Aviron, S., Ernoult, A., Fahrig, L., Burel, F., 2014a. Reconsidering the role of "semi-natural habitat" in agricultural landscape biodiversity: a case study. Ecol. Res. 30, 75-83. https://doi.org/10.1007/s11284-014-1211-9 
418 Duflot, R., Ernoult, A., Aviron, S., Fahrig, L., Burel, F., 2017. Relative effects of 419 landscape composition and configuration on multi-habitat gamma diversity in 420 agricultural landscapes. Agric. Ecosyst. Environ. 241, 62-69.

$421 \quad$ https://doi.org/10.1016/j.agee.2017.02.035

422 Duflot, R., Ernoult, A., Burel, F., Aviron, S., 2016. Landscape level processes driving 423 carabid crop assemblage in dynamic farmlands. Popul. Ecol. 58, 265-275.

424 https://doi.org/10.1007/s10144-015-0534-x

425

426

427

428

429

430

431

432

433

434

435

436

437

438

Duflot, R., Georges, R., Ernoult, A., Aviron, S., Burel, F., 2014b. Landscape heterogeneity as an ecological filter of species traits. Acta Oecologica 56, 19-26. https://doi.org/10.1016/j.actao.2014.01.004

Dufrêne, M., 1992. Biogéographie et écologie des communautés de Carabidae en Wallonie (Doctoral dissertation, Université catholique de Louvain, Louvain-laNeuve,Belgique).

Eyre, M.D., Luff, M.L., Leifert, C., 2013. Crop, field boundary, productivity and disturbance influences on ground beetles (Coleoptera, Carabidae) in the agroecosystem. Agric. Ecosyst. Environ. 165, 60-67. https://doi.org/10.1016/j.agee.2012.12.009

Fahrig, L., Girard, J., Duro, D., Pasher, J., Smith, A., Javorek, S., King, D., Lindsay, K.F., Mitchell, S., Tischendorf, L., 2015. Farmlands with smaller crop fields have higher within-field biodiversity. Agric. Ecosyst. Environ. 200, 219-234. https://doi.org/10.1016/j.agee.2014.11.018 
439 Fournier, E., Loreau, M., 2001. Respective roles of recent hedges and forest patch

440 remnants in the maintenance of ground-beetle (coleoptera: Carabidae) diversity in

441 an agricultural landscape. Landsc. Ecol. 16, 17-32.

$442 \quad$ https://doi.org/10.1023/A:1008115516551

443 Fox, J. and Weisberg S., 2011. An $\{R\}$ Companion to Applied Regression, Second $444 \quad$ Edition. Thousand Oaks CA: Sage. URL:

$445 \quad$ http://socserv.socsci.mcmaster.ca/jfox/Books/Companion

446 Fried, G., Petit, S., Dessaint, F., Reboud, X., 2009. Arable weed decline in Northern

$447 \quad$ France: Crop edges as refugia for weed conservation? Biol. Conserv. 142, 238-

$448 \quad$ 243. https://doi.org/10.1016/j.biocon.2008.09.029

449 Gabriel, D., Sait, S.M., Hodgson, J. a, Schmutz, U., Kunin, W.E., Benton, T.G., 2010.

450 Scale matters: the impact of organic farming on biodiversity at different spatial 451 scales. Ecol. Lett. 13, 858-69. https://doi.org/10.1111/j.1461-0248.2010.01481.x

452 Gagic, V., Bartomeus, I., Jonsson, T., Taylor, A., Winqvist, C., Fischer, C., Slade, E.M., 453 Steffan-dewenter, I., Emmerson, M., Potts, S.G., Tscharntke, T., Weisser, W., 454 Bommarco, R., 2015. Functional identity and diversity of animals predict ecosystem 455 functioning better than species-based indices. Proc. R. Soc. B Biol. Sci. 282, $456 \quad$ 20142620. https://doi.org/10.1098/rspb.2014.2620

457 Hanson, H.I., Palmu, E., Birkhofer, K., Smith, H.G., Hedlund, K., 2016. Agricultural land 458 use determines the trait composition of ground beetle communities. PLoS One 11, 459 1-13. https://doi.org/10.1371/journal.pone.0146329 
460 Hof, A.R., Bright, P.W., 2010. The impact of grassy field margins on macro-invertebrate 461 abundance in adjacent arable fields. Agriculture, Ecosyst. Environ. 139, 280-283. $462 \quad$ https://doi.org/10.1016/j.agee.2010.08.014

463 Holland, J.M., Luff, M.L., 2000. The effects of agricultural practices on Carabidae in 464 temperate agroecosystems. Integr. Pest Manag. Rev. 5, 109-129.

$465 \quad$ https://doi.org/10.1023/A:1009619309424

466

467

468

469

470

471 Hurvich CM, Tsai CL., 1989. Regression and time series model selection in small $472 \quad$ samples. Biometrika 76:297-307

473

474

475

476

477

Honek, A., Martinkova, Z., Saska, P., Pekar, S., 2007. Size and taxonomic constraints determine the seed preferences of Carabidae (Coleoptera). Basic Appl. Ecol. 8, 343-353. https://doi.org/10.1016/j.baae.2006.07.002

Hothorn T., Bretz F., Westfall P., 2008. Simultaneous Inference in General Parametric Models. Biometrical J. 50, 346--363.

Kleijn, D., Baquero, R. a, Clough, Y., Díaz, M., De Esteban, J., Fernández, F., Gabriel, D., Herzog, F., Holzschuh, a, Jöhl, R., Knop, E., Kruess, a, Marshall, E.J.P., Steffan-Dewenter, I., Tscharntke, T., Verhulst, J., West, T.M., Yela, J.L., 2006. Mixed biodiversity benefits of agri-environment schemes in five European countries. Ecol. Lett. 9, 243-54. https://doi.org/10.1111/j.1461-0248.2005.00869.x 
478 Kotze, D.J., O'Hara, R.B., 2003. Species decline--but why? Explanations of carabid 479 beetle (Coleoptera, Carabidae) declines in Europe. Oecologia 135, 138-48. $480 \quad$ https://doi.org/10.1007/s00442-002-1174-3

481 Kromp, B., 1999. Carabid beetles in sustainable agriculture: A review on pest control 482 efficacy, cultivation impacts and enhancement. Agric. Ecosyst. Environ. 74, 187$483 \quad 228$. https://doi.org/10.1016/S0167-8809(99)00037-7

484

485 Labruyere, S., Bohan, D.A., Biju-Duval, L., Ricci, B., Petit, S., 2016. Local, neighbor and 486 landscape effects on the abundance of weed seed-eating carabids in arable fields: 487 A nationwide analysis. Basic Appl. Ecol. 17, 230-239.

488 https://doi.org/10.1016/j.baae.2015.10.008

489

490

491

492

493

494

495

496

497

Labruyere, S., Petit, S., Ricci, B., 2017. Annual variation of oilseed rape habitat quality and role of grassy field margins for seed eating carabids in arable mosaics. Agric. For. Entomol. https://doi.org/10.1111/afe.12250

Laliberté, E., Legendre, P., 2010. A distance-based framework for measuring functional diversity from multiple traits. Ecology 91, 299-305. https://doi.org/10.1890/082244.1

Laliberté, E., Legendre, P., Shipley B.,2014. FD: measuring functional diversity from multiple traits, and other tools for functional ecology. R package version 1.0-12. 
498 MacLeod, A., Wratten, S.D., Sotherton, N.W., Thomas, M.B., 2004. "Beetle banks" as 499 refuges for beneficial arthropods in farmland: Long-term changes in predator 500 communities and habitat. Agric. For. Entomol. 6, 147-154.

$501 \quad$ https://doi.org/10.1111/j.1461-9563.2004.00215.x

502 Magura, T., Lövei, G.L., Tóthmérész, B., 2017. Edge responses are different in edges 503 under natural versus anthropogenic influence: a meta-analysis using ground 504 beetles. Ecol. Evol. 7, 1009-1017. https://doi.org/10.1002/ece3.2722

505 Mauremooto, J.R., Wratten, S.D., Worner, S.P., Fry, G.L.A., 1995. Permeability of 506 hedgerows to carabid beetles. Agric. Ecosyst. Environ. 52, 141-148.

507 Neumann, J.L., Griffiths, G.H., Hoodless, A., Holloway, G.J., 2016. The compositional 508 and configurational heterogeneity of matrix habitats shape woodland carabid 509 communities in wooded-agricultural landscapes. Landsc. Ecol. 31, 301-315. $510 \quad$ https://doi.org/10.1007/s10980-015-0244-y

511 Oksanen, J., Kindt, R., Legendre, P., O'Hara, B., Simpson, G.L., Solymos, P., Stevens, 512 M.H.H. and Wagner, H., 2008. The vegan package. Community ecology 513 package.[http://r-forge. r-project. org/projects/vegan/].

514 Pakeman, R.J., Stockan, J.A., 2014. Drivers of carabid functional diversity: abiotic 515 environment, plant functional traits, or plant functional diversity? Ecology 95, 1213$516 \quad$ 1224. https://doi.org/10.1890/13-1059.1

517 Piqueray, J., Richard, C., Walot, T., Le Roi, A., de Tillesse, M., Hance, T., Mahy, G., 518 2013. Proceedings of the conference: "Nature, conditionnalité et verdissement de la 
519 PAC : un tournant wallon ?". 9th November 2011. Espace Senghor, Gembloux, $520 \quad$ Belgium. Biotechnol. Agron. Soc. Environ. 17, 344-351.

521 Prasad, R.P., Snyder, W.E., 2006. Polyphagy complicates conservation biological 522 control that targets generalist predators. J. Appl. Ecol. 43, 343-352.

$523 \quad$ https://doi.org/10.1111/j.1365-2664.2006.01129.x

524 Purtauf, T., Roschewitz, I., Dauber, J., Thies, C., Tscharntke, T., Wolters, V., 2005.

525 Landscape context of organic and conventional farms: Influences on carabid beetle 526 diversity. Agric. Ecosyst. Environ. 108, 165-174.

527 https://doi.org/10.1016/j.agee.2005.01.005

528 R Core Team (2013). R: A language and environment for statistical computing. R $529 \quad$ Foundation for Statistical Computing, Vienna, Austria.

530 Ribera, I., Foster, G.N., Downie, I.S., McCracken, D.I., Abernethy, V.J., 1999. A 531 comparative study of the morphology and life traits of Scottish ground beetles 532 (Coleoptera, Carabidae). Ann. Zool. Fennici 36, 21-37.

533 Roger, J.L., Jambon, O. and Bouger, G., 2013. Clé de détermination des Carabidae, $534 \quad$ Paysages agricoles du Nord Ouest de la France.

535 Roume, A., Deconchat, M., Raison, L., Balent, G., Ouin, A., 2011. Edge effects on 536 ground beetles at the woodlot-field interface are short-range and asymmetrical.

537 Agric. For. Entomol. 13, 395-403. https://doi.org/10.1111/j.1461-

$538 \quad 9563.2011 .00534 . x$ 
539 RStudio Team (2016). RStudio: Integrated Development for R. RStudio, Inc., Boston, $540 \quad$ MA http://www.rstudio.com/.

541 Rusch, A., Birkhofer, K., Bommarco, R., Smith, H.G., Ekbom, B., 2015. Predator body 542 sizes and habitat preferences predict predation rates in an agroecosystem. Basic $543 \quad$ Appl. Ecol. 16, 250-259. https://doi.org/10.1016/j.baae.2015.02.003

544 Saska, P., and Jarosik V., 2001. Laboratory study of larval food requirements in nine 545 species of Amara (Coleoptera: Carabidae). Plant Protect. Sci. Prague. 37, 103-110.

546 Saska, P., Vodde, M., Heijerman, T., Westerman, P., van der Werf, W., 2007. The 547 significance of a grassy field boundary for the spatial distribution of carabids within 548 two cereal fields. Agric. Ecosyst. Environ. 122, 427-434.

$549 \quad$ https://doi.org/10.1016/j.agee.2007.02.013

550 Saska, P., Van Der Werf, W., De Vries, E., Westerman, P.R., 2008. Spatial and 551 temporal patterns of carabid activity-density in cereals do not explain levels of 552 predation on weed seeds. Bull. Entomol. Res. 98, 169-181.

553 https://doi.org/10.1017/S0007485307005512

554 Stoate, C., Boatman, N.D., Borralho, R.J., Carvalho, C.R., De Snoo, G.R., Eden, P., 555 2001. Ecological impacts of arable intensification in Europe. J. Environ. Manage. $556 \quad$ 63, 337-365. https://doi.org/10.1006/jema.2001.0473

557 Trichard, A., Alignier, A., Biju-Duval, L., Petit, S., 2013. The relative effects of local 558 management and landscape context on weed seed predation and carabid 
559 functional groups. Basic Appl. Ecol. 14, 235-245.

$560 \quad$ https://doi.org/10.1016/j.baae.2013.02.002

561 Vanbergen, A.J., Woodcock, B.A., Watt, A.D., Niemelii, J., 2005. Effect heterogeneity

562 scale landscape at the on carabid communities of land-use. Ecography. 28, 3-16.

563 Woodcock, B.A., Redhead, J., Vanbergen, A.J., Hulmes, L., Hulmes, S., Peyton, J., $564 \quad$ Nowakowski, M., Pywell, R.F., Heard, M.S., 2010. Impact of habitat type and 565 landscape structure on biomass, species richness and functional diversity of 566 ground beetles. Agric. Ecosyst. Environ. 139, 181-186.

$567 \quad$ https://doi.org/10.1016/j.agee.2010.07.018

568 Woodcock, B.A., Westbury, D.B., Potts, S.G., Harris, S.J., Brown, V.K., 2005.

569 Establishing field margins to promote beetle conservation in arable farms. Agric.

570 Ecosyst. Environ. 107, 255-266. https://doi.org/10.1016/j.agee.2004.10.029 


\section{Figure 1}

\section{Geographical location of study sites and experimental design}

(a) Geographical emplacement in Europe of the Walloon region (in light blue) in Belgium (dark blue lines);

(b) Localisation of the three study sites in Wallonia; (c) Experimental design included for each study site four configurations of ecological infrastructures (EI) at the border of crops : single hedge $(\mathrm{H})$, single grassy strip $(G)$, association of a hedge to an annual flower strip $(H+A)$ and association of a grassy strip to an annual flower strip $(G+A)$. Carabids were captured in pitfall traps (black dots) positionned on transect lines in all $\mathrm{El}$, as well as in crops at two and $30 \mathrm{~m}$ from the edge.

(c) EuroGeographics. Original product is freely available at eurogeographics.org. Terms of the licence available at https://eurogeographics.org/products-and-services/open-data/topographic-data/.

*Note: Auto Gamma Correction was used for the image. This only affects the reviewing manuscript. See original source image if needed for review.

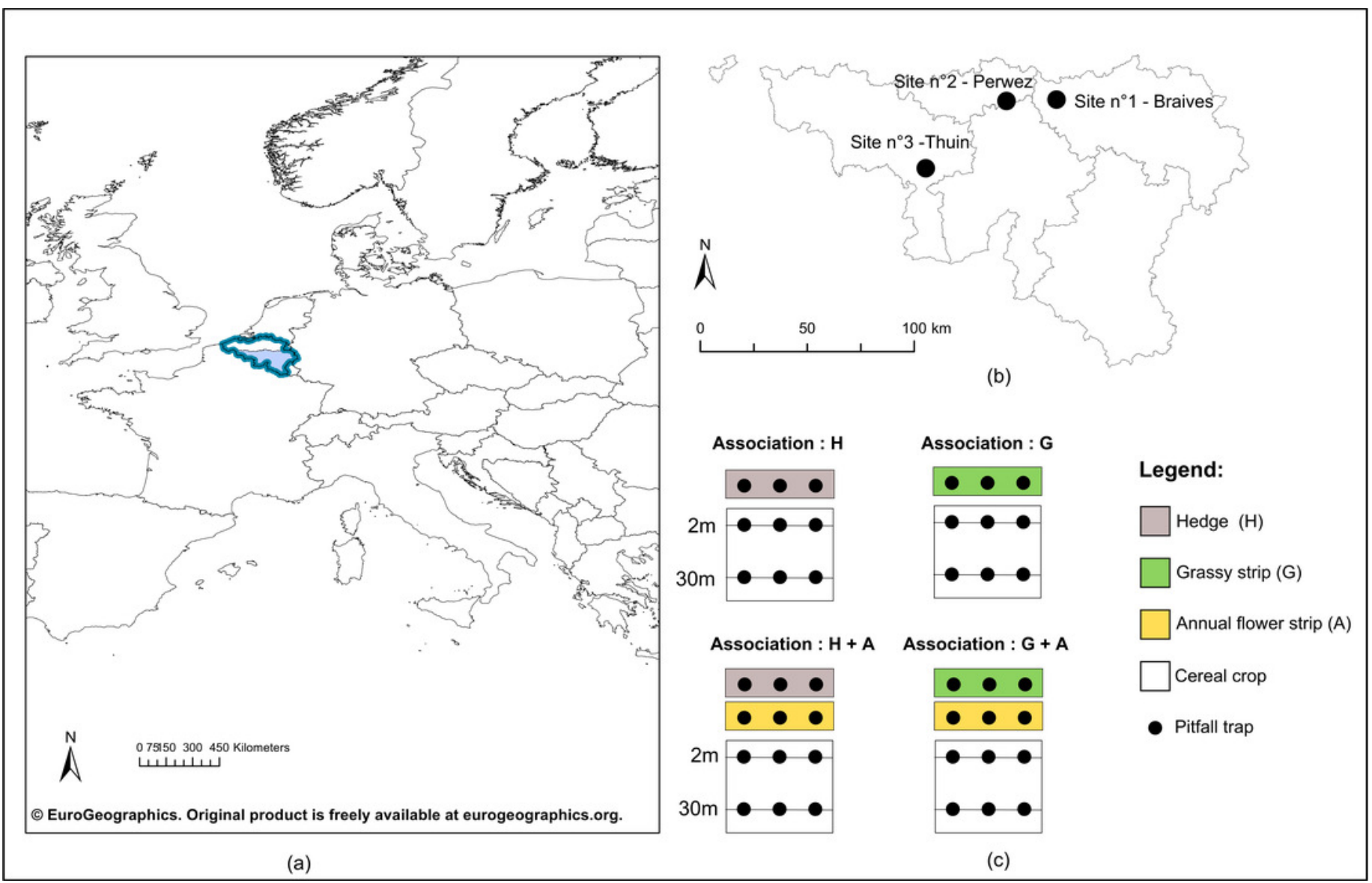




\section{Figure 2}

Carabid assemblages similarities between ecological infrastructures (EI) and crops by Principal Coordinate Anaysis (PCoA)

This PCoA displays the distribution of: (a) transects (i.e. sum of the three traps during all catching period) from all three study sites (grey dots). Transects are grouped under label centroids representing each type of ecological infrastructures and crops (C2 = crops ( $2 \mathrm{~m}$ from the edge); $\mathrm{C} 30=\operatorname{crops}(30 \mathrm{~m}$ from the edge); $\mathrm{A}=$ annual flower strips; $\mathrm{G}=$ grassy strips; $\mathrm{H}=$ hedges); (b) carabid species and their activity-density, proportional to the circles size. The complete list of carabid species is available in Annex 2.

*Note: Auto Gamma Correction was used for the image. This only affects the reviewing manuscript. See original source image if needed for review. 


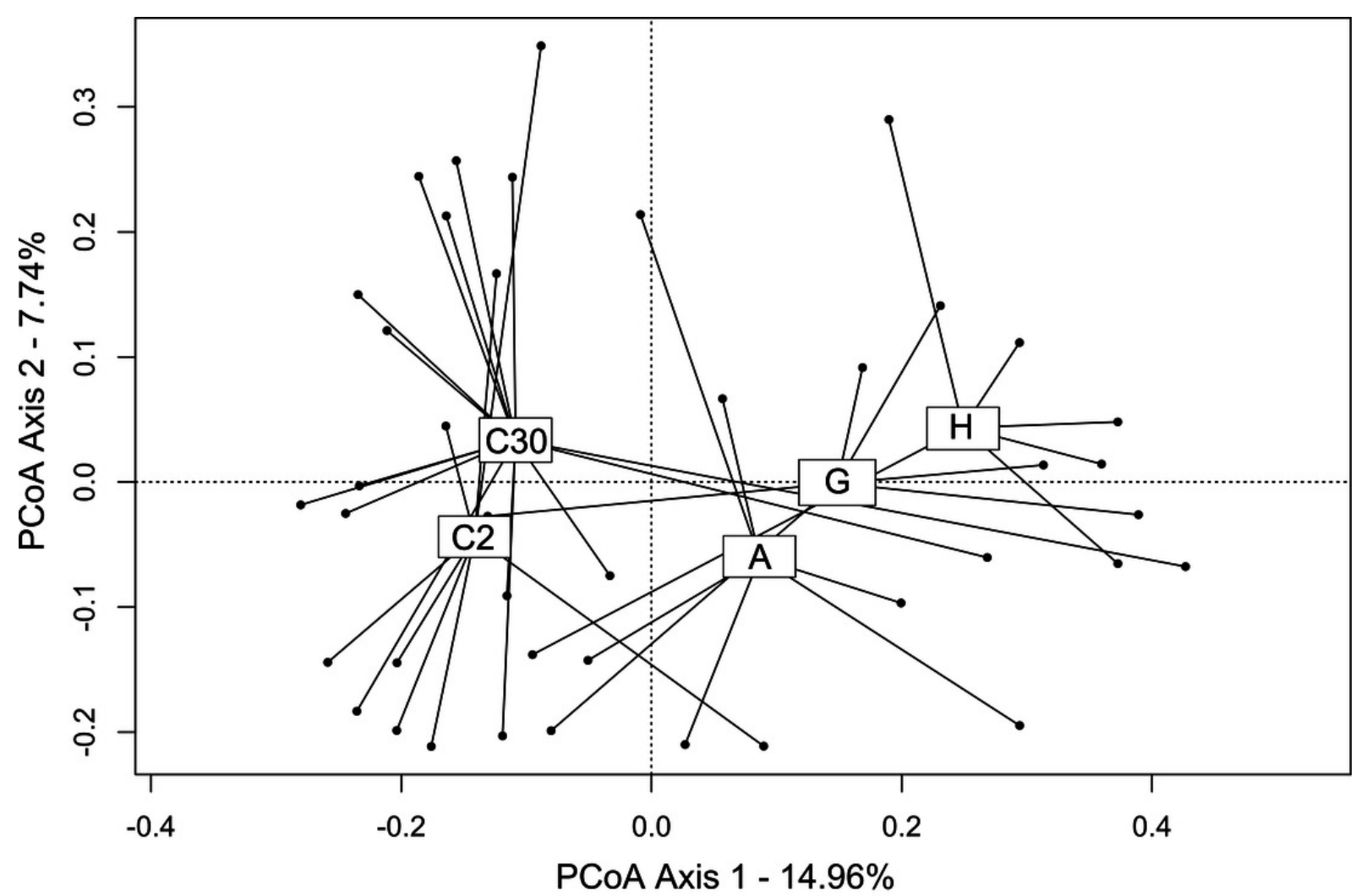

(a)

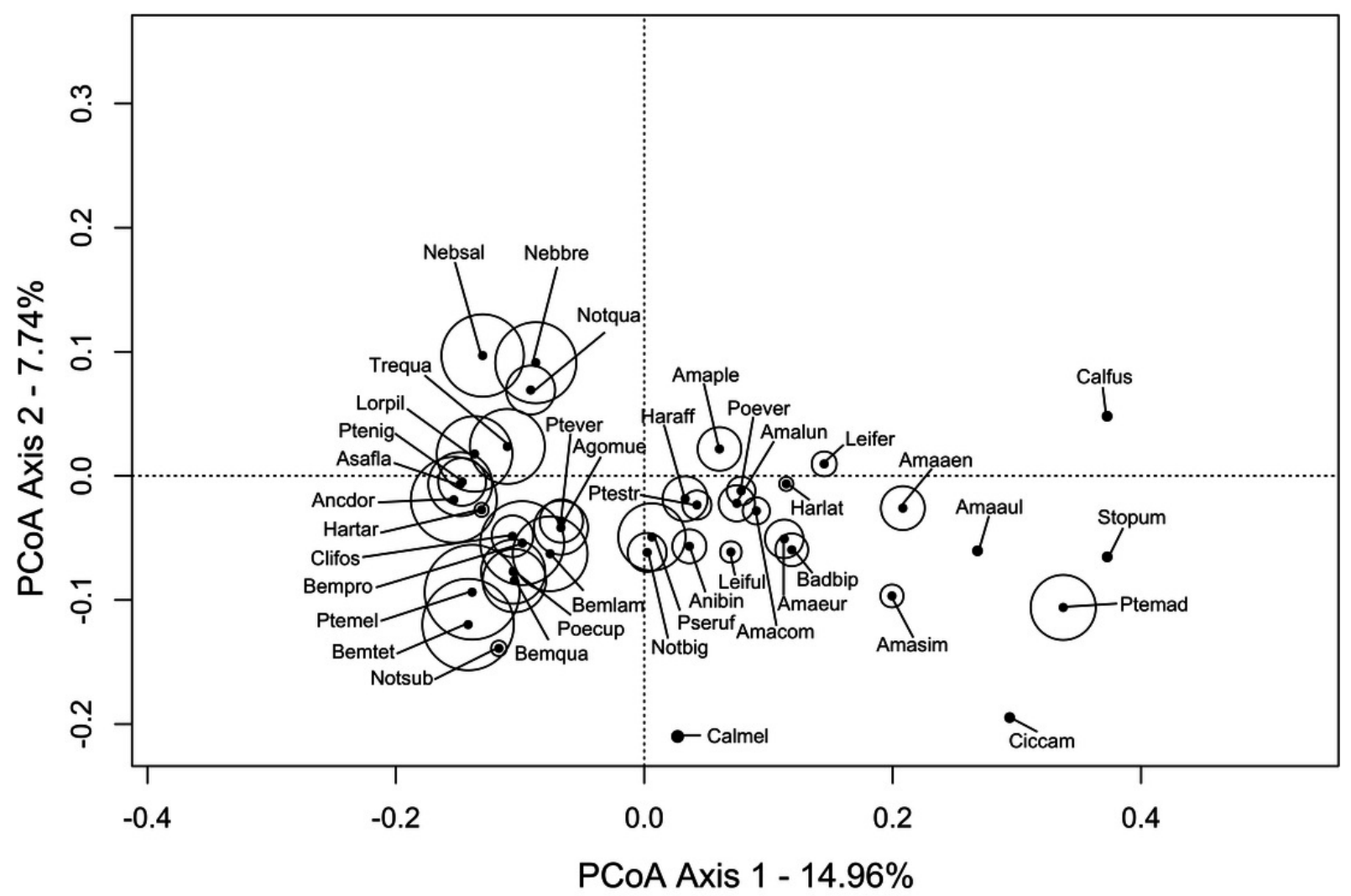

(b) 


\section{Figure 3}

Boxplots of functional traits of interest from crop carabid assemblages (by transects). Presented plots display variables that responded significantly to the type of ecological infrastructure.

Significant LMs concerned: (a) Community weighted mean (CWM) size; (b) Carabids of small size $(<5 \mathrm{~mm})$ and (c) Proportion of spring breeders. Ecological infrastructures are abbreviated as follow: $\mathrm{H}=$ hedges; $\mathrm{G}=$ grassy strips; $A=$ annual flower strips). Distance from the crop border is given by the shade of the boxes (light grey $=2 \mathrm{~m}$ from the border; dark grey $=30 \mathrm{~m}$ from the border). Letters above the plots indicate the results of the post-hoc Tukey test performed on the GLMs.

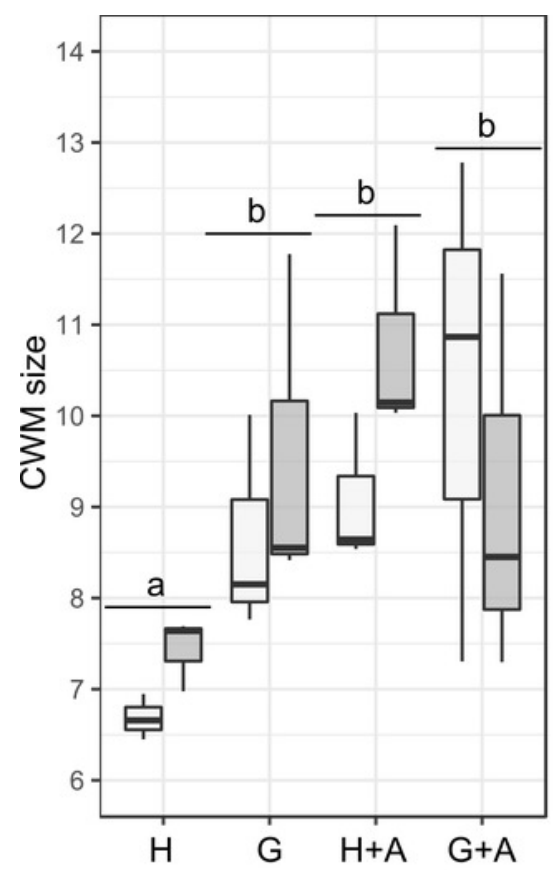

(a)

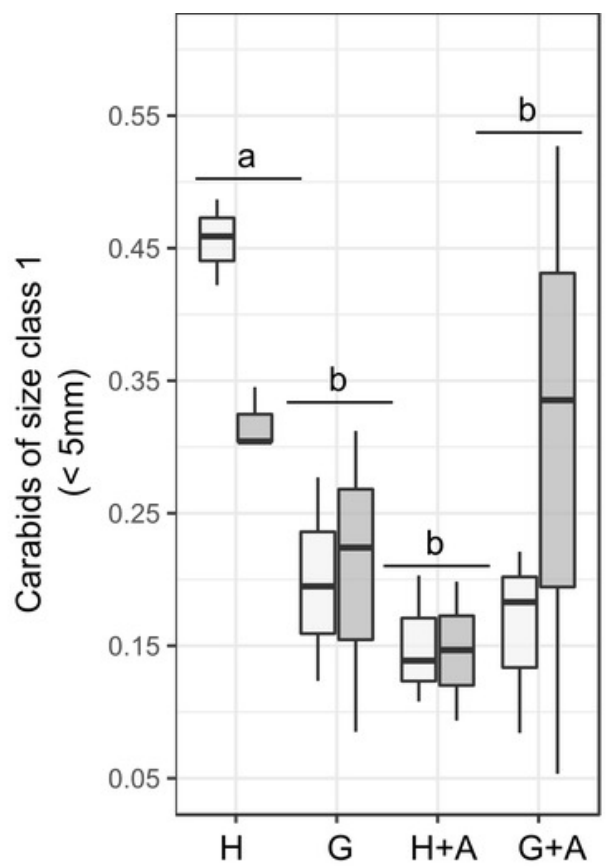

(b)

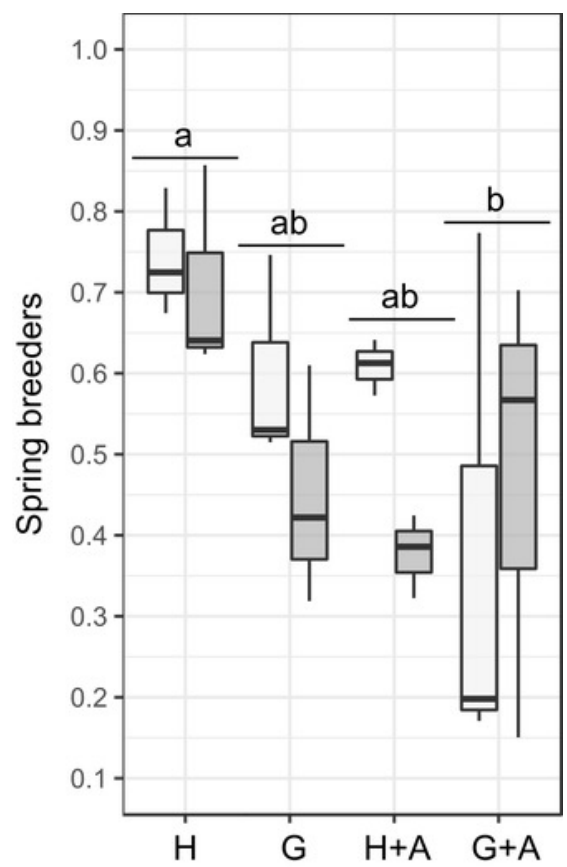

(c) 


\section{Table $\mathbf{1}$ (on next page)}

Proportions of selected functional traits (\%) and CWM size in carabid assemblages from each ecological infrastructures (EI) and from crops

Proportions of individuals displaying the traits of interest are given by transect (averaged values for three traps). Els and crops are abbreviated as follow: $H=$ Hedges; $G=$ Grassy strips; $A=$ Annual flowers trips; $C 2=$ Crops ( $2 \mathrm{~m}$ from the edge); $C 30=$ Crops $(30 \mathrm{~m}$ from the edge). 
1

\begin{tabular}{cccccccccccccccc}
\hline & \multicolumn{4}{c}{ Size class (\%) } & \multicolumn{4}{c}{ Wing (\%) } & & \multicolumn{3}{c}{ Breeding } \\
period (\%)
\end{tabular}

2 * 'Specialist predators' refer to species feeding mainly on Collembola while 'Generalist predators' have a wider panel of preys 


\section{Table 2 (on next page)}

Diversity indices of carabid assemblages from ecological infrastructures (EI) and crops

Mean values of carabid activity-density, species richness and FDis index per transect (sum of three traps) for each type of $\mathrm{El}$ and crops. Error is given by the standard deviation. Els and crops are abbreviated as follow: $\mathrm{H}=$ Hedges; $\mathrm{G}=$ Grassy strips; $\mathrm{A}=$ Annual flowers trips; $\mathrm{C2}$ $=$ Crops $(2 \mathrm{~m}$ from the edge); $\mathrm{C} 30=$ Crops $(30 \mathrm{~m}$ from the edge). 
1

\begin{tabular}{cccc}
\hline Type of EI & Activity-density & Species diversity & FDis \\
\hline H & $73.06 \pm 78.48$ & $11.33 \pm 4.97$ & $0.25 \pm 0.12$ \\
G & $82.06 \pm 65.21$ & $14.33 \pm 5.13$ & $0.29 \pm 0.04$ \\
A & $142.11 \pm 30.88$ & $18.67 \pm 5.13$ & $0.32 \pm 0.09$ \\
C2 & $246.56 \pm 160.81$ & $16.08 \pm 2.58$ & $0.27 \pm 0.04$ \\
C30 & $269.06 \pm 208.66$ & $16.17 \pm 2.21$ & $0.27 \pm 0.04$ \\
\hline
\end{tabular}

2 


\section{Table 3 (on next page)}

Results of the Generalized Linear Models applied on a selection of variables (per transect), testing both the type of ecological infrastructures and the distance from the crops' border on carabid assemblages in crops.

Models included the type of ecological infrastructure along the crop ("Type") and the distance from the crop border ("Distance"). Akaike Information Criterion corrrected for small samples (AICC), $\triangle$ AICC and AICC weight (wAICc) are given for every model. Selected models ( $\triangle \mathrm{AICc}<2$ ) are written in bold. Non-Gaussian distribution models are specified in brackets (italic) for the concerned variables. 
1

\begin{tabular}{lccc}
\hline \multicolumn{1}{c}{ Variables } & AICc & $\Delta$ AIC & wAIC \\
\hline $\begin{array}{l}\text { Activity-density } \\
\text { (log distribution) }\end{array}$ & & & \\
$\sim$ Type * Distance & 64.2 & 20.25 & 0.000 \\
$\sim$ Type + Distance & 50.3 & 6.35 & 0.027 \\
$\sim$ Distance & 46.5 & 2.57 & 0.177 \\
$\sim$ Type & 46.8 & 2.81 & 0.157 \\
$\sim$ 1 & $\mathbf{4 4 . 0}$ & $\mathbf{0 . 0 0}$ & $\mathbf{0 . 6 4 0}$
\end{tabular}

Species richness

(Poisson distribution)

$\sim$ Type * Distance

139.8

18.06

0.000

$\sim$ Type + Distance

7.30

0.018

$\sim$ Distance

2.39

0.208

$\sim$ Type

4.07

0.089

$\sim 1$

125.8

0.00

0.685

FDis

$\sim$ Type * Distance

24.48

0.000

$\sim$ Type + Distance

10.77

0.003

$\sim$ Distance

2.45

0.222

$\sim$ Type

7.36

0.019

$\sim 1$

0.00

0.755

CWM size

$\sim$ Type * Distance

111.1

12.81

0.001

$\sim$ Type + Distance

101.0

2.72

0.164

$\sim$ Distance

103.4

5.09

0.050

$\sim$ Type

98.3

0.00

0.641

$\sim 1$

101.3

3.00

0.143

Spring breeders

$\begin{array}{lccr}\sim \text { Type } * \text { Distance } & 7.4 & 12.34 & 0.001 \\ \sim \text { Type + Distance } & -2.8 & 2.15 & 0.128 \\ \sim \text { Distance } & \mathbf{- 3 . 1} & \mathbf{1 . 8 2} & \mathbf{0 . 1 5 2} \\ \sim \text { Type } & \mathbf{- 5 . 0} & \mathbf{0 . 0 0} & \mathbf{0 . 3 7 6} \\ \sim \mathbf{1} & \mathbf{- 4 . 8} & \mathbf{0 . 1 8} & \mathbf{0 . 3 4 3}\end{array}$


Autumn breeders

$$
\begin{aligned}
& \sim \text { Type } * \text { Distance } \\
& \sim \text { Type }+ \text { Distance } \\
& \sim \text { Distance } \\
& \sim \text { Type } \\
& \sim \mathbf{1}
\end{aligned}
$$

0.00

0.376

Generalist predators

$\sim$ Type * Distance

$\sim$ Type + Distance

6.85

0.020

Distance

$-22.0$

1.44

0.301

$\sim$ Type

4.66

0.060

$\sim 1$

$-18.8$

0.00

0.618

Specialist predator

$$
\begin{aligned}
& \sim \text { Type } * \text { Distance } \\
& \sim \text { Type }+ \text { Distance } \\
& \sim \text { Distance } \\
& \sim \text { Type } \\
& \sim \mathbf{1}
\end{aligned}
$$$$
-52.8
$$$$
24.23
$$$$
0.000
$$$$
-65.9
$$$$
11.13
$$$$
0.003
$$

2.62

0.208

7.54

0.018

0.00

0.771

Omnivorous

(log distribution)

$\sim$ Type * Distance

$-16.4$

18.00

0.000

$\sim$ Type + Distance

$-28.6$

5.77

0.033

$\sim$ Distance

$-33.0$

1.40

0.290

$\sim$ Type

$-30.7$

3.68

0.093

$\sim 1$

$-34.4$

0.00

0.585

Size class $1(<5 \mathrm{~mm})$

$\sim$ Type * Distance

$-19.1$

10.53

0.004

$\sim$ Type + Distance

$-26.1$

3.60

0.131

$\sim$ Distance

$-21.6$

8.03

0.014

$\sim$ Type

$-29.7$

0.00

0.797

$\sim 1$

$-24.3$

5.41

0.053

Size class 2

$(5 \mathrm{~mm}<\mathrm{X} \leq 10 \mathrm{~mm})$

$\sim$ Type * Distance

$-12.0$

11.79

0.001 
$\sim$ Type + Distance

$-20.0$

3.78

$-23.5$

$-20.5$

$-23.7$

$\sim 1$

Size class 3

$(10 \mathrm{~mm}<\mathrm{X} \leq 15 \mathrm{~mm})$

(log distribution)

$\sim$ Type * Distance

8.7

$-4.5$

$-7.4$

$-4.6$

$-7.3$

$\sim 1$

Size class 4 ( $>15 \mathrm{~mm})$

(log distribution)

$\sim$ Type * Distance

$\sim$ Type + Distance

Distance

$\sim$ Type

$-15.0$

$-25.6$

$-31.9$

$-28.2$

$-33.7$

0.20

3.27

0.00

16.10

0.000

2.85

0.098

0.00

0.406

2.76

0.102

0.06

0.395

$\sim 1$
18.65

0.000

8.06

0.012

1.72

0.281

5.49

0.043

0.00

0.665

2

3 


\section{Table 4 (on next page)}

Deviance table calculated on the selected GLMs explaining best the variables describing carabid assemblages in crops.

Significant models $(p<0.05)$ are written in bold. 


\begin{tabular}{lllcc}
\hline \multicolumn{1}{c}{ Variables } & Selected model & d.f & L.R $\chi^{2}$ & P value \\
\hline Activity-density & $\sim 1$ & - & - & - \\
Species richness & $\sim 1$ & - & - & - \\
FDis & $\sim 1$ & - & - & - \\
CWM size & $\sim$ Type & 3 & 12.64 & $\mathbf{0 . 0 0 5}$ \\
Spring/Autumn & $\sim$ Type & 3 & 9.03 & $\mathbf{0 . 0 2 9}$ \\
breeders & $\sim$ Distance & 1 & 0.93 & 0.335 \\
Generalist predators & $\sim$ Distance & 1 & 1.12 & 0.290 \\
Specialist predators & $\sim 1$ & - & - & - \\
Omnivorous & $\sim$ Distance & 1 & 1.15 & 0.283 \\
Class 1 & $\sim$ Type & 3 & 16.09 & $\mathbf{0 . 0 0 1}$ \\
Class 2 & $\sim$ Distance & 1 & 2.35 & 0.126 \\
Class 3 & $\sim$ Distance & 1 & 2.60 & 0.107 \\
Class 4 & $\sim$ Distance & 1 & 0.85 & 0.358 \\
& & & &
\end{tabular}




\section{Table 5 (on next page)}

AIC values for GLS models with and without correlation structure

All three variables (CMW size, Size class 1 and Spring breeders) were tested as a function of the type of ecological infrastructures. 


\begin{tabular}{cccc}
\hline & & AIC values & \\
\hline Correlation structure & $\begin{array}{c}\text { Community Weighted } \\
\text { Mean (CMW) Size }\end{array}$ & $\begin{array}{c}\text { Size class } 1 \\
(<5 \mathrm{~mm})\end{array}$ & Spring breeders \\
\hline No correlation structure & 91.62312 & -15.01437 & 5.573410 \\
corExp & 95.62312 & -11.01437 & 7.784194 \\
corLin & 95.62312 & -11.01437 & 8.829442 \\
corGaus & 95.62312 & -11.01437 & 7.225125 \\
corSpher & 95.62312 & -11.01437 & 8.829442 \\
corRatio & 95.62312 & -11.01437 & 7.695223 \\
\hline
\end{tabular}

1

2 